\title{
The Effect of Biotechology Module with Problem Based Learning in the Socioscientific Context to Enhance Students' Socioscientific Decision Making Skills
}

\author{
Luthfiana Nurtamara ${ }^{1}$, Sajidan $^{1}$, Suranto $^{2} \&$ Nanik Murti Prasetyanti ${ }^{3}$ \\ ${ }^{1}$ Postgraduate Program of Biology Education, Faculty of Teacher Training and Education, Universitas Sebelas \\ Maret, Surakarta, Indonesia \\ ${ }^{2}$ Department of Biology, Faculty of Mathematics and Sciences, Universitas Sebelas Maret, Surakarta, Indonesia \\ ${ }^{3}$ SMA Negeri 3 Surakarta, Surakarta, Indonesia \\ Correspondence: Sajidan, Department of Biology Education, Faculty of Teacher Training and Education \\ Universitas Sebelas Maret, Jalan Ir. Sutami 36 Kentingan, Jebres, Surakarta, Jawa Tengah, Indonesia.
}

Received: July 9, 2019

Accepted: September 18, 2019

Online Published: December 17, 2019

doi:10.5539/ies.v13n1p11

URL: https://doi.org/10.5539/ies.v13n1p11

\begin{abstract}
This aim of the research was to train socioscientific decision making skills for the science students. Students are involved to solve the socioscientific problems by making informative and systematic decisions. The development of socioscientific decision making skills was done by applying biotechnological module based on Problem-based Learning with socioscientific cases. Quasi-experimental design was used in this research. Two science classes were employed in this research: first class for experimental class which had the treatment by applying biotechnology module based on problem-based learning and another class for control class using biology books from school. Those two classes were given the same questions in pre-test and post-test to measure socioscientific decision making skills. The research results showed that the average post-test score of socioscientific decision making skills in experimental class was 82.80 which is higher than the control class (62.32); moreover, normalized gain score in experimental class obtaining 0.745 and this is also higher than that in control class (0.434). The results of ANCOVA analysis show, that there was significant differences in the score of socioscientific decision making skills between experimental class and the control one by the value of $\mathrm{F}$ count (25.54), this value was higher than $\mathrm{F}$ table (4.075). In addition, the score of partial eta squared was 0,384 , which means that the application of PBL-based module with socioscientific cases have the high level of effectiveness to improve socioscientific decision making skills. The result of assessment transcript in the decision making quality showed that experimental class has the decision supported by the justified arguments which is contains 2-4 socioscientific aspects.
\end{abstract}

Keywords: socioscientific decision making, module biotechnology, problem based learning

\section{Introduction}

\subsection{Background of the Study}

The 21 st century which is called an information era; senerally, students have more opportunity in gaining knowledge, by synthesizing and integrating information from various disciplines (Brookhart, 2010; Tan, 2015). The learning process in 21 st century usually use a learning context that contains multidisciplinary issues (Morris, 2014). The multidisciplinary issues can stimulate students to make decisions or solutions to socioscientific issues supported by scientific evidence-based arguments (Owens, Sadler, \& Zeidler, 2017). Socioscientific issues (SSI) are controversial issues in a modern society involving concepts, procedures, or technology in science (Sadler \& Donnelly, 2006). Decisions related to SSI problems are made by considering multidisciplinary aspects which are science, economics, environment, culture, ethics/morals, and regulations (Morris, 2014; Walker \& Zeidler, 2007).

Science literacy in educational research can be empowered by decision-making skills in socioscientific issues (Böttcher \& Meisert, 2013). The aim of scientific literacy measurement in PISA is to involve students in science issues; hence, students become reflective societies (OECD, 2016). PISA scores of Indonesian students are ranged between 357.77 and 420.07; which means that the ability of Indonesian students is only at level 1 (score 393 in 
2006; score of 383 in 2009; 382 in 2012; 403 in 2015); this means that, Indonesian students have the ability to use basic knowledge and procedural knowledge to recognize or identify explanations of simple scientific phenomena (Malley \& Kelly, 2015; OECD, 2013, 2016; PISA, 2006). The science curriculum in Germany has implemented socioscientific decision making to improve the the average of PISA scores of German students (Bögeholz, Eggert, Ziese, \& Hasselhorn, 2017). The results of pre-test in socioscientific decision making skill showed the students' low socioscientific decision making skills in describing, developing, and evaluating the solution to a problem. Research conducted by Grace (2009) showed that students find the difficulties to evaluate solutions made by considering the advantages and disadvantages of alternative solutions to reflect the decisions that are taken.

Problems in the application of biotechnology can be used as a socio-scientific context (Simonneaux, 2007). According to Purwianingsih et al. (2009), teachers have difficulties in obtaining biotechnology teaching materials that suit the latest scientific developments and have constraints dealing with English language skills in learning biotechnology teaching materials, so that biotechnology learning is restricted only by using LKS (Student Worksheet) and Indonesian-language textbooks. The results of observations at the school showed that the students only used one LKS as a source of teaching materials and biotechnology material that is mostly presented through theories for the students to memorize. The results of the observation analysis are supported by the research finding of Zohar \& Dori (2003); noted that most textbooks contain facts to be memorized and tested for students because the focus of education is still driven by the assessment of educational science literacy in 20th century through reading, writing, and arithmetic. According to Dori et al,. (2003), teaching biotechnology modules that use controversy case studies can improve understanding, knowledge, and high order thinking skills.

Problem-based learning (PBL) learning activities have the potential to develop socioscientific decision making skills because PBL can make students define problems, investigate problems, give solutions to problems, and carry out evaluation processes (Awang dan Ramly, 2008). Socioscientific problems are ill-structured (Chung, Yoo, Kim, Lee, \& Zeidler, 2014; Sadler \& Zeidler, 2004). The ill-structured problem is used in PBL learning which states that it is impossible to have one correct answer, so students can consider and negotiate to provide alternative solutions supported by reasonable arguments to support the chosen solution (Hmelo-Silver \& Barrows, 2008).

\subsection{Socioscientific Decision Making}

Sosioscientific decision making is used to make decisions about a problem involving the negotiation process in science conflicts, evaluating the feasibility of claims, considering risk based on evidence, and making pro and contra of alternative decisions which are made based on ethical, environmental, and social perspectives (Eggert et al., 2013; Hsu \& Lin, 2017; Lee \& Grace, 2012; Troy, 2004). The assessment components of socioscientific decision making based on literature studies are as follows: (1) describing socioscientific issues is a skill to explain SSI problem by considering various aspects of SSI such as morality, ethics, economics, and environment (2) developing solution is a skill to create more than one solutions of complex problems, and (3) evaluating solution: a skill to compare and evaluate several possible solutions to problems and to reflect on the decision making process. Assessment of socioscientific decision making skills in this study could be used to measures those three components using the rubric of Eggert et al. (2013).

Decision-making processes related to SSI problems involve informal reasoning processes out of the logical context of symbols and mathematics through searching for and evaluating information, building pro and contra of the arguments from alternative decisions in order to reach conclusions of actions to be taken (Rundgren, Eriksson, \& Rundgren, 2016; Zohar \& Nemet, 2002). Skills to make and evaluate arguments are used as the basis for informal reasoning (Dawson \& Venville, 2009). The argument plays a role in considering each alternative solution by using more than one science theory and technical information to explain one of SSI problems (Acar, Turkmen, \& Roychoudhury, 2010). High-quality decisions and solutions are supported by functional reasoning, justified arguments, and consideration of each alternative solution (Grace, 2009). The justified argument is the ability to make a claim using evidence and to justify the relationship between claims and evidence in each alternative that is made (Bathgate, Crowell, Schunn, Cannady, \& Dorph, 2015). Thus, students need to learn presenting arguments to support decisions and to determine attitudes or positions in solving SSI problems. The purpose of this study is also to measure the quality of the arguments produced by students in making decisions based on the rubric of Grace (2009).

\subsection{Problem Based Learning (PBL)}

PBL is a constructivist learning that provides student-centered learning through collaborative learning (Günter, 2018). Students work in collaborative groups during learning to compare theories and problem solving strategies guided by facilitators (Hmelo-Silver, 1998). Barrows (1983) suggests to implement PBL by forming a small group consisting of 5-6 students with a tutor as facilitator. The main core of PBL learning is asking students to make a 
logical solution to a problem (Meyer, 2018).

PBL learning stages according to Chua, Tan, and Liu (2016) and Tan (2002) are as follows: (1) Meeting the problem; (2) Problem analysis and learning issues; (3) discovery and reporting; (4) Solution presentation and evaluating. The first and second stage of PBL model can develop describing socioscientific skills through identifying and describing SSI problems by considering various aspects such as social, economic and ecological aspect (Bögeholz et al., 2017; Kolarova, Hadjiali, \& Denev, 2013). The next stage is discovery and reporting done through compiling information about problems and discussing in groups to use relevant information to the problem as evidence that supports the solution (Chua et al., 2016). The final stage is comparing and evaluating several alternative solutions by considering the positive and negative effects or the pros and cons of the chosen solution (Acar et al., 2010; Eggert et al., 2013; Hsu \& Lin, 2017). The aim of PBL learning is to develop socioscientific decison making skills as Tan (2002) stated that collaborative processes in PBL learning require negotiation and evaluation of understanding to construct a knowledge.

\subsection{Biotechnology as Socioscientific Issues}

Biotechnology is a technology that applies living things and or biological processes to solve a problem (Garrett, 2009). The basic material of biotechnology for high school students in Indonesia contained in the revised version of Minister of Education and Culture Regulation Number 69 of 2013 that includes analyzing the biotechnology principles and its implementation as an effort to improve human welfare. The observation and textbook analysis result shows that textbook used by students biotechnology materials that are studied are conventional biotechnology, tissue culture, animal cloning, recombinant DNA, hybridoma technology, and IVF. The implementation of biotechnology has a major impact on society, hence it involves communities to make decisions and be critical of the implementation of biotechnology (Fonseca, Costa, Lencastre, Tavares, \& Joa, 2012; Klop \& Severiens, 2007). Modern biotechnology learning for students aged 15 to 19 years, according to Kolarova (2014), can invite students to take critical decisions and attitudes towards the implementation of modern biotechnology in society. Khishfe (2012) provides the task for students to make decisions and arguments about the issue of animal cloning and genetically modified organisms (GMOs). This research presented a test of socioscientific decison making to students under the topic of implementation of planting transgenic golden rice and Bt corn in the society as well as cases of cloning dead animals in biotechnology companies.

\subsection{Reaseach Question}

Based on the background described above, PBL-based biotechnology modules are needed with socio-scientific problems to improve sociosaintific decision making skills. The research questions that arise are:

1) How is the effectiveness of PBL-based biotechnology modules with socioscientific context to improve socioscientific decision skills of the high school students in Surakarta?

2) How is the quality level of decisions the students make?

\section{Method}

\subsection{Research Design}

This research was design of a quasi-experimental. The experimental class was treated by the application of PBL-based biotechnology modules with socioscientific problems, while the control class was treated using biology books from schools. Both classes were given pre-test and post-test of socioscientific decision making skill. Analysis of the results of the pre-test and post-test in quasi-experimental used ANCOVA (Ary, Jacobs, Sorensen, \& Raavieh, 2010). Meanwhile the measurement of the effectiveness of independent variables in educational research using partial eta squared with small, medium, and large criteria from Cohen (Richardson, 2011). Measurement of the improvement of socioscientific decision making skills before treatment and after treatment used Normalized gain $<\mathrm{g}>$ from Hake (2001) as seen below:

$$
<\mathrm{g}>=\frac{(\%<\text { post }- \text { test }>-\%<\text { pre }- \text { test }>)}{(100-\%<\text { pre }- \text { test }>}
$$

\subsection{The Sample}

The research participants of this research were twelfth-grade science students by using 2 intact classes in Surakarta. One class was chosen as experimental class using PBL with socioscientific problems containing 21 students and another class was chosen as control class using textbook from school containing 23 students.

\subsection{The Instrument}

Data on SSI DM skills were obtained through written tests in the form of essay questions consisting of six 
questions which cover aspects of the socioscientific decision making skills of the assessment rubric (Eggert et al., 2013). They consisted of describing socioscientific issues, developing solution, and evaluating solution. The scoring of essay test item uses 1-3 intervals based on criteria SSI decision making rubric. The instrument was tested first on 25 students who had studied biotechnology to measure the validity and reliability of each test instrument. The validity of the essay test instrument was conducted with Pearson's Product Moment and reliability test was conducted by Alpa Crobach (Saputri, Sajidan, Rinanto, Afandi, \& Prasetyani, 2019). The results of the validity test obtained the lowest score at 0.406 and the highest score at 0.846 , means that the instrument of SSI decision making skill are valid ( $r$ statistics $>r_{\text {table }}=0.396$ ). The result of reliability test showed that Alpha Cronbach is $0.775>\mathrm{r}_{\text {table }}=0.396$, meaning that each of item test is reliable. The quality of decision making revealed by students was measured using the rubric of Grace (2009).

\section{Results}

\subsection{Socioscientific Decision Making Skills}

The average socioscientific decision making skill taught using PBL-based modules with socioscientific cases has a value of 82.80 which is higher than the control class (62.32). Descriptive statistical results of socioscientific decision making skills are presented in Table 1.

Table 1. The result of pre-test and post-test of socioscientific decision making skills data

\begin{tabular}{cccccc}
\hline Measure & Classes & Mean & Min scores & Max scores & Sd \\
\hline \multirow{2}{*}{ Pretes } & Experiment & 32.45 & 11.11 & 72.22 & 13.64 \\
& Control & 33.33 & 11.11 & 55.66 & 13.30 \\
\multirow{2}{*}{ Postes } & Experiment & 82.80 & 66.67 & 100 & 10.96 \\
& Control & 62.32 & 55.56 & 83.33 & 16.41 \\
\hline
\end{tabular}

Pre-test and post-test data on socioscientific decision making skills were analyzed using ANCOVA. Result of ANCOVA test of $(p$-value $=0.00 ;$ Fcount $=25.544>$ Ftable $=4.075)$ showed that there were significant differences between students taught using PBL-based Biotechnology Modules with socio-scientific cases and those using biology books from schools. The ANCOVA test results using SPSS 25 are presented in Table 2.

Table 2. The result of ancova analysis in socioscientific decision making skills data

\begin{tabular}{lcccccc}
\hline Source & Type III Sum of Squares & Df & Mean Square & F & Sig. & Partial Eta Squared \\
\hline Corrected Model & $5362.613^{\mathrm{a}}$ & 2 & 2681.307 & 14.525 & .000 & .415 \\
Intercept & 23387.394 & 1 & 23387.394 & 126.689 & .000 & .756 \\
PRETES & 755.987 & 1 & 755.987 & 4.095 & .050 & .091 \\
TREATMEN & 4715.530 & 1 & 4715.530 & 25.544 & .000 & .384 \\
Error & 7568.783 & 41 & 184.604 & & & \\
Total & 241635.803 & 44 & & & & \\
Corrected Total & 12931.397 & 43 & & & & \\
a. R Squared $=.415$ (Adjusted R Squared $=.386)$ & & & &
\end{tabular}

Table 2 showed the effectiveness of PBL-based biotechnology module with socioscientific cases that have the partial eta squared score of 0.384 . The effectiveness of using PBL-based modules in empowering students' SSI DM skills is 0.384 which is classified as a massive effect according to Gignac \& Szodorai (2016). The calculation of normalized gain to find out the improvement of socioscientific decision making skills is presented in Table 3 .

Table 3. The result of normalized gain $<\mathrm{g}>$ socioscientific decision making skills data

\begin{tabular}{lcc}
\hline Classes & Normalized gain $<\mathrm{g}>$ & Criteria \\
\hline Experiment & 0.745 & High \\
Control & 0.434 & Medium \\
\hline
\end{tabular}

Table 3 shows that the improvement in the score of socioscientific decision making skills before and after treatment in the experimental class is higher. Normalized gain in the experimental group is 0.745 which means that 
the score improvement is high, while the gain in the control group is 0.434 which means the score improvement is at the moderate level. Based on the gain scores, the experimental group using PBL-based biotechnology modules can increase the higher score of SSI DM skills than the control group that uses biology books from the school.

\subsection{The Quality of Students Decision Making}

Post-test data shows a variety of respondents' answers for the same question. The data of decisions revealed by students in the post-test are then assessed using the rubric of Grace (2009). A sample transcript of the quality of student decision-making is presented in Table 4 and the frequency of the quality of decision making produced by students is presented in Table 5 .

Table 4. Transcript of the qulity of students' decision making

\begin{tabular}{|c|c|c|}
\hline & Decision & Component \\
\hline $\begin{array}{l}\text { Level } \\
1\end{array}$ & $\begin{array}{l}\text { It is better to be resolved by discussion to reach consensus. } \\
\text { It is better to adopt animals than to conduct pets cloning }\end{array}$ & $\begin{array}{l}\text { solutions made by students are } \\
\text { not accompanied by justified } \\
\text { arguments }\end{array}$ \\
\hline $\begin{array}{c}\text { Level } \\
2\end{array}$ & $\begin{array}{l}\text { The community remains in the old way without Bt corn so that the ecosystem is not disrupted. } \\
\text { It is better if the people who have lost their beloved pets must leave them due to a destiny. }\end{array}$ & $\begin{array}{l}\text { Decisions made by the students } \\
\text { are partly justified }\end{array}$ \\
\hline $\begin{array}{c}\text { Level } \\
3\end{array}$ & $\begin{array}{l}\text { "I think it must be produced and marketed because high levels of vitamin A in golden rice can } \\
\text { help human being in reducing blindness in childhood." } \\
\text { "The attitude of the people who lose their loving pets is through cloning technology because } \\
\text { with the characteristics can be exactly the same as a donor cell which is their loving pets" }\end{array}$ & $\begin{array}{l}\text { Students make decisions by the } \\
\text { statement supported by justified } \\
\text { arguments }\end{array}$ \\
\hline $\begin{array}{c}\text { Level } \\
4\end{array}$ & $\begin{array}{l}\text { "I think the golden rice has no need to be produced and marketed because the consumption of } \\
\text { vitamin A can be obtained rom other commodities, such as carrot, tomato, which are better to be } \\
\text { optimized dealing with its production." } \\
\text { "Golden rice is better to be produced and marketed, but the benefit and negative effects of the } \\
\text { product must be listed in the packaging so that people are able to choose wisely. }\end{array}$ & $\begin{array}{l}\text { Decisions are accompanied by } \\
\text { justified arguments along with } \\
\text { the alternatives without } \\
\text { considering the effectiveness of } \\
\text { the alternatives chosen. }\end{array}$ \\
\hline $\begin{array}{l}\text { Level } \\
5\end{array}$ & $\begin{array}{l}\text { In my opinion, it must be produced and marketed because high levels of vitamin A in golden rice } \\
\text { can help reducing blindness in childhood. Golden rice is rice modified by the addition of PSY } \\
\text { gene from daffodils and CrtI from eweinia. Golden rice can help preventing blindness by } \\
\text { increasing Vitamin A intake during the digestive process. However, rice production must always } \\
\text { be monitored and maintained/restricted; hence, other rice are not contaminated by the genetic } \\
\text { material of golden rice. } \\
\text { If I lose the animal myself, I will not look for other animals to clone. Besides the price is } \\
\text { expensive, it also violates the nature of the Almighty. Nonetheless, if there are other people who } \\
\text { really do not sincerely lose their animals and have money to make a clone, please go on. The } \\
\text { process of cloning animals with the same characteristics as those that are cloned. Taking one of } \\
\text { the animal cells which is then reproduced used a scientific process in the laboratory so that it } \\
\text { becomes an animal that has the same nature as the cloned animal. But in my opinion, this is not } \\
\text { good because it does not recognize the gift of God and violates His nature. " }\end{array}$ & $\begin{array}{l}\text { Giving alternative solutions by } \\
\text { considering explicit } \\
\text { consideration of function and } \\
\text { goal of each chosen alternative. }\end{array}$ \\
\hline
\end{tabular}

Table 5. Frequency of the quality of students decision making in control and experimental class

\begin{tabular}{ccccc}
\hline & \multicolumn{2}{c}{ Control Class } & \multicolumn{2}{c}{ Experimental Class } \\
\cline { 2 - 5 } & Frequency & Percentage (\%) & Frequency & Percentage (\%) \\
\hline Level 1 & 12 & 10.71 & 1 & 0.95 \\
Level 2 & 57 & 50.89 & 14 & 13.33 \\
Level 3 & 29 & 25.89 & 38 & 36.19 \\
Level 4 & 12 & 10.71 & 36 & 34.29 \\
Level 5 & 2 & 1.8 & 16 & 15.24 \\
\hline
\end{tabular}

The implementation of PBL-based Biotechnology Module can produce higher quality decision-making compared to the control class. The experimental students were mostly at level 3 with a percentage of $36,19 \%$, which means that most students have been able to make decisions along with justified arguments. Meanwhile, level 4 with a percentage of $34.29 \%$ means that students have been able to make decisions accompanied by alternative considerations. In the students' control class, the most is at level 2 with a percentage of $50.89 \%$ and level 3 with a 
percentage of $25.89 \%$.

\section{Discussion}

The topic of biotechnology that has drawn much controversy in students is the topic of planting transgenic plants and cloning pets, so that the topic is used as a pre-test and post-test to measure students' SSI DM skills. In the experimental, class students were involved to identify farmers' problems in overcoming corn stem borer and cloning pets linking it with the knowledge they had to formulate problems and hypotheses. In the next stage, namely the problem of learning and learning issues, students are asked to formulate a problem and hypothesis.

Resolvement of students' problem is carried out at the stage of discovery and reporting by gathering information about the process of making transgenic plants and the process of cloning dead animals in biotech companies. Information on the manufacture of transegnic plants and cloning technology can be used as evidence to make decisions by understanding the usefulness of biotechnology for the benefit of human life and its impact on ecology, economics and society. The decision making process invites students to evaluate and consider relevant information (Eggert \& Bogeholz, 2009). The stages of information gathering involve the students to respond the controversy over the implementation of biotechnology products that occur in the community, for example the case of Bt corn planting by giving a statement from Greenpeace (2009):

Ecological systems ensure healthy farming and healthy food today and in the future, and do not contaminate the environment with chemical inputs or genetic engineering.

Based on the pros and cons occurred in the community, students are invited to measure the advantages and disadvantages of the choices that are made in consuming or not consuming transgenic plant products, namely at the stage of solution presentation and evaluating by presenting solutions or decisions and discussing them. Examples of decisions taken by students are as follows:

As a stakeholder, I will stop planting Bt corn because the result of engineering it can affect its habitat, these changes affect the natural predators of target pests, from the inability to recognize their prey until they die as victims. Plants around the corn field will also be polluted with Bt corn pollen (the decision contains the ecological and environmental aspects of the impact of Bt corn planting).

I will choose the recombinant DNA technology process to eradicate plant borers. Eradicating pests in this way will make plants more resistant to pests, herbicides, and plant disease attacks; hence, it increases crop production and creates new varieties. Nevertheless, there remain risks that must be taken including: disrupting ecosystems, the emergence of health or allergic disorders in humans and living creatures around them, increasing insecticide resistance to insect pests and killing beneficial insects such as butterflies. (the decision contains aspects of the economy, ecology, environment and health and there is a relationship among aspects).

Socioscientific decision in the case of transgenic plants made by students in the experimental group contains 2-4 socioscientific aspects, whereas control group only needed to present the results of group discussions without being asked to write a solution or final decision after learning activities. Resolvement of socioscientific problems in PBL-based biotechnology modules was carried out in the experimental group by identifying problems, collecting relevant information, compiling various choices of solutions, and comparing the choices made by comparing the advantages and disadvantages of each solution to make the best decision. The effect of the treatment makes the results of post-test measurements for each aspect of the SSI DM skills of the experimental group have a higher order, namely 92.06, 81,74, and 74.6, compared to the control group namely 71.74, 57.97 and 57.2.

Learning using PBL-based biotechnology modules can be an effective solution to improve SSI DM skills because Pepper (2010) states that PBL learning involves students to decide information and skills to investigate problems by building knowledge from the existing knowledge and by integrating it into new information. PBL-based learning in accordance with Gagne's learning theory is to provide problems that must be analyzed, synthesized, and must evaluate the solutions made; hence, the students can encode new information and improve memory information that is obtained (Gagne in Driscoll, 2000).

Socioscientific problem is an opened and unstructured problem and does not have a definite solution (Sadler \& Zeidler, 2004). Socio-scientific decision making involves the process of negotiating uncertainty on claims and evaluating claims made based on evidence that involves reasoning about cause and effect and considering the pros and cons of alternative decisions with multiperspective thinking (Lee \& Grace, 2012). Argumentation skills are needed by students to make decisions and to solve SSI problems by building and evaluating arguments as well as justifying decisions made in writing or speech (Dawson \& Carson, 2018). Based on the description it can be seen that the argument is a statement or conclusion that supports the decision in resolving the sociosocial case, so this 
study assesses the quality of student decision making supported by arguments

The results of the quality decision-making assessment show that students who learn to use the PBL-based Biotechnology Module with socioscientific cases have a higher frequency of quality decision making than those who use biology books from school. The implementation of PBL-based biotechnology modules can involve students to be informed and have systematic decisions or solutions. The results of this research are supported by research conducted by Dori, Tal, \& Tsaushu (2003) showing that learning using modules with controversial biotechnology cases can make students form questions, find and evaluate evidence, and convey decisions or solutions with arguments in accordance with several aspects of SSI such as health, social and moral. Children who are able to survive in the 21 st century are those who can do a project, find solutions, communicate it, and have social skills (Abadzi, 2016).

\section{Conclusion}

Training decision-making skills for science students is very important in order to educate students into a literary society. Students' decision-making skills are trained using the PBL syntax by resolving socioscientific issues from implementing biotechnology in society during conducting this study. That study effectively enhance skill of students in socioscientific decision making which has partial eta squared value of 0,384 . Based on PBL syntax, it is recorded that student has capability in indentifying and determining the socioscientific decision making which are supported by justified arguments. Many variety of student argumentations in answering GMO plants and pet cloning as well as their controversies, has resulted pro and contra particulary in answering their final decision. Pro and contra made by student in final socioscentific decision making were considered not only in the enviromental, health, and moral aspects but also for the economic sector. Based on the above evidences, it is concluded that the highest quality for students' decision making ussualy contain at least two sosioscientific aspects which are supported by justified arguments.

\section{Acknowledgments}

We would like to thanks Headmaster of SMAN 3 Surakarta, who has given permission to this research.

\section{References}

Abadzi, H. (2016). Training 21st-century workers: Facts, fiction and memory illusions. International Review of Education, 62(3), 253-278. https://doi.org/10.1007/s11159-016-9565-6

Acar, O., Turkmen, L., \& Roychoudhury, A. (2010). Student difficulties in socio-scientific argumentation and decision-making research findings: Crossing the borders of two research lines. International Journal of Science Education, 32(9), 1191-1206. https://doi.org/10.1080/09500690902991805

Ary, D., Jacobs, C., Sorensen, C., \& Raavieh, A. (2010). Introduction to Research in Education (8th ed.). Belmont, USA: Nelson Education, Ltd.

Awang, H., \& Ramly, I. (2008). Creative Thinking Skill Approach Through Problem-Based Learning : Pedagogy and Practice in the Engineering Classroom. International Journal of Educational and Pedagogical Sciences, 2(4), 334-339. Retrieved from waset.org/Publication/15369

Barrows, H. S. (1983). Problem-Based, Self-directed Learning. JAMA, 250(22), 4-7. https://doi.org/https://doi.org/10.1001/jama.1983.03340220045031

Bathgate, M., Crowell, A., Schunn, C., Cannady, M., \& Dorph, R. (2015). The learning benefits of being willing and able to engage in scientific argumentation. International Journal of Science Education, 37(10), 1590-1612. https://doi.org/https://doi.org/10.1080/09500693.2015.1045958

Bögeholz, S., Eggert, S., Ziese, C., \& Hasselhorn, M. (2017). Modeling and Fostering Decision-Making Competencies Regarding Challenging Issues of Sustainable Development Competence Model for Decision Making with Respect. In Competence Assessment in Education (pp. 263-283). https://doi.org/10.1007/978-3-319-50030-0

Böttcher, F., \& Meisert, A. (2013). Effects of direct and indirect instruction on fostering decision-making competence in socioscientific issues. Research in Science Education, 43(2), 479-506. https://doi.org/10.1007/s11165-011-9271-0

Brookhart, S. M. (2010). How to assess higher-order thinking skills in your classroom. Alexandria, USA: ASCD.

Chua, B. L., Tan, O. S., \& Liu, W. C. (2016). Journey into the problem-solving process: cognitive functions in a PBL environment. Innovations in Education and Teaching International, 53(2), 191-202. https://doi.org/10.1080/14703297.2014.961502 
Chung, Y., Yoo, J., Kim, S., Lee, H., \& Zeidler, D. L. (2014). Enhancing students' communication skills in the science classroom through socioscientific issues. International Journal of Science and Mathematics Education, 14(1), 1. https://doi.org/10.1007/s10763-014-9557-6

Dawson, V., \& Carson, K. (2018). Introducing argumentation about climate change socioscientific issues in a Disadvantaged School. Research in Science Education, 1-21. https://doi.org/10.1007/s11165-018-9715-x

Dawson, V., \& Venville, G. J. (2009). International journal of science high-school students' informal reasoning and argumentation about biotechnology: An indicator of scientific literacy? International Journal of Science Education, 31(11), 1421-1445. https://doi.org/10.1080/09500690801992870

Dori, Y. J., Tal, R. T., \& Tsaushu, M. (2003). Teaching Biotechnology Through Case Studies-Can We Improve Higher Order Thinking Skills of Nonscience Majors? Science Education, 87(6), 767-793. https://doi.org/10.1002/sce.10081

Driscoll, M. P. (2000). Gagne's Theory of Instruction. In Psychology of Learning for Instruction (pp. 341-373). Boston: MA: Allyn and Bacon.

Eggert, S., \& Bogeholz, S. B. (2009). Students' use of decision-making strategies with regard to students' use of decision-making strategies with regard to socioscientific issues: An application of the rasch partial credit model. Science Education, 94(2), 230-258. https://doi.org/10.1002/sce.20358

Eggert, S., Ostermeyer, F., Hasselhorn, M., \& Bögeholz, S. (2013). Socioscientific Decision Making in the Science Classroom: The Effect of Embedded Metacognitive Instructions on Students' Learning Outcomes. Education Research International, 2013, 1-12. https://doi.org/10.1155/2013/309894

Fonseca, M. J., Costa, P., Lencastre, L., Tavares, F., \& Joa, M. (2012). Multidimensional analysis of high-school students' perceptions about biotechnology. Journal of Biological Education, 46(3), 129-139. https://doi.org/10.1080/00219266.2011.634019

Garrett, S. T. (2009). Professional development for the integration of biotechnology education (Unpublished masters of education thesis). Queensland University of Technology.

Gignac, G. E., \& Szodorai, E. T. (2016). Effect size guidelines for individual differences researchers. PAID, 102, 74-78. https://doi.org/10.1016/j.paid.2016.06.069

Grace, M. (2009). Developing high quality decision-making discussions about biological conservation in a normal classroom setting. International Journal of Science Education, 31(4), 551-570. https://doi.org/10.1080/09500690701744595

Günter, T. (2018). Effectiveness of a Problem-Based Learning (PBL) scenario for enhancing academic achievement of energy metabolism. Research in Science Education, 1-25. https://doi.org/10.1007/s11165-018-9750-7

Hake, R. R. (2001). Lessons from the physics-education reform effort. Conserv Ecol, 5(2), 1-61. https://doi.org/10.5751/ES-00286-050228

Hmelo-Silver, C. E. (1998). Problem-based learning: Effects on the early acquisition of cognitive skill in medicine. Journal of the Learning Sciences, 7(2), 173-208. https://doi.org/10.1207/s15327809j1s0702_2

Hmelo-Silver, C. E., \& Barrows, H. S. (2008). Facilitating collaborative knowledge building. Cognition and Instruction, 26(1), 48-94. https://doi.org/10.1080/07370000701798495

Hsu, Y. S., \& Lin, S. S. (2017). Prompting students to make socioscientific decisions: embedding metacognitive guidance in an e-learning environment. International Journal of Science Education, 39(7), 964-979. https://doi.org/10.1080/09500693.2017.1312036

Khishfe, R. (2012). Nature of science and decision-making. International Journal of Science Education, 34(1), 67-100. https://doi.org/10.1080/09500693.2011.559490

Klop, T., \& Severiens, S. (2007). An Exploration of Attitudes towards Modern Biotechnology : A study among Dutch secondary school students An Exploration of Attitudes towards Modern Biotechnology: A study among Dutch secondary school students. International Journal of Science Education, 29(5), 37-41. https://doi.org/10.1080/09500690600951556

Kolarova, T. (2014). Modern biotechnology from the point of view of 15-19-year-old high school students. Biotechnology \& Biotechnological Equipment, 25(3), 2538-2546. https://doi.org/10.5504/BBEQ.2011.0069

Kolarova, T., Hadjiali, I., \& Denev, I. (2013). High school students' reasoning in making decisions about 
socio-ethical issues of genetic engineering : Case of gene therapy education \& basic science. Biotechnology \& Biotechnological Equipment, 27(3), 3737-3747. https://doi.org/10.5504/BBEQ.2012.0133

Lee, Y. C., \& Grace, M. (2012). Students' reasoning and decision making about a socioscientific issue: A cross-context comparison. Science Education, 96(5), 787-807. https://doi.org/10.1002/sce.21021

Malley, L., \& Kelly, D. (2015). Testing Sampler: Trying Out TIMSS and PISA. Washington: U.S. Departement of Education. Retrieved from https://www.ewa.org

Meyer, H. (2018). Teachers' thoughts on student decision making during engineering design lessons. Educ. Sci, 8(9), 1-11. https://doi.org/10.3390/educsci8010009

Morris, H. (2014). Socioscientific issues and multidisciplinarity in school science textbooks socioscientific issues and multidisciplinarity in school science textbooks. International Journal of Science Education, 36(7), 1137-1158. https://doi.org/10.1080/09500693.2013.848493

OECD. (2013). PISA 2012 Assessment and Analytical Framework: Mathematics, Reading, Science, Problem Solving and Financial Literacy. OECD Publishing. https://doi.org/10.1787/9789264190511-en

OECD. (2016). PISA 2015 Assessment and Analytical Framework: Science, Reading, Mathematic and Financial Literacy. Paris: OECD Publishing. https://doi.org/10.1787/9789264281820-en

Owens, D. C., Sadler, T. D., \& Zeidler, D. L. (2017). Controversial issues in the science classroom. Phi Delta Kappan, 99(4), 45-49. https://doi.org/10.1177/0031721717745544

Pepper, C. (2010). "There's a lot of learning going on but NOT much teaching!": Student perceptions of problem-based learning in science. Higher Education Research and Development, 29(6), 693-707. https://doi.org/10.1080/07294360.2010.501073

PISA. (2006). PISA Science Literacy Items and Scoring Guides (pp. 1-48). Retrieved from https://nces.ed.gov/surveys/pisa/pdf/items2_science.pdf

Purwianingsih, W., Rustaman, N., \& Redjeki, S. (2009). Identifikasi Kesulitan Pembelajaran Bioteknologi pada Guru SLTA se Jawa Barat. Seminar Nasional Inovasi Biologi Dan Pendididkan Biologi Dalam Pengembangan Sumber Daya Manusia, 15-16.

Richardson, J. T. E. (2011). Eta squared and partial eta squared as measures of effect size in educational research. Educational Research Review, 6(2), 135-147. https://doi.org/10.1016/j.edurev.2010.12.001

Rundgren, C., Eriksson, M., \& Rundgren, S. C. (2016). Investigating the intertwinement of knowledge, value , and experience of upper secondary students' argumentation concerning socioscientific issues. Sci \& Educ, 25, 1049-1071. https://doi.org/10.1007/s11191-016-9859-x

Sadler, T. D. (2004). Moral and ethical dimensions of socioscientific decision-making as integral components of scientific literacy. Science Educator, 13(1), 39-48. Retrieved from files.eric.ed.gov

Sadler, T. D., \& Donnelly, L. A. (2006). Socioscientific Argumentation: The effects of content knowledge and morality Socioscientific Argumentation: International Journal of Science Education, 28(12), 1463-1488. https://doi.org/10.1080/09500690600708717

Sadler, T. D., \& Zeidler, D. L. (2004). Patterns of informal reasoning in the context of socioscientific decision making. Journal of Research in Science Teaching, 42(1), 112-138. https://doi.org/10.1002/tea.20042

Saputri, A., Sajidan, Rinanto, Y., Afandi, \& Prasetyani, N. (2019). Improving students' critical thinking skills in cell-metabolism learning using stimulating higher order thinking skills model. International Journal of Instruction, 12(1), 328-342. https://doi.org/10.29333/iji.2019.12122a

Simonneaux, L. (2007). Argumentation in Socio-Scientific Contexts. In Argumentation in Science Education (pp. 179-199). Dordrecht, The Netherlands: Springer. https://doi.org/10.1007/978-1-4020-6670-2_9

Tan, O. S. (2015). Innovating teacher education in a complex era. Educational Research for Policy and Practice, 14(3), 193-200. https://doi.org/10.1007/s10671-015-9181-4

Tan, O.-S. (2002). Problem-based Learning: More problems for teacher education. Review of Educational Research and Advances for Classroom Teacher, 21(1), 43-55. Retrieved from https://repository.nie.edu.sg

Walker, K. A., \& Zeidler, D. L. (2007). Promoting discourse about socioscientific issues through scaffolded inquiry. International Journal of Science Education, 29(11), 1387-1410. https://doi.org/10.1080/09500690601068095 
Zohar, A., \& Dori, Y. J. (2003). Higher order thinking skills and low-achieving students: Are they mutually exclusive? Journal of the Learning Sciences, 12(2), 145-181. https://doi.org/10.1207/S15327809JLS1202_1

Zohar, A., \& Nemet, F. (2002). Fostering students' knowledge and argumentation skills through dilemmas in human genetics. Journal of Research in Science Teaching, 39(1), 35-62. https://doi.org/10.1002/tea.10008

\section{Copyrights}

Copyright for this article is retained by the author(s), with first publication rights granted to the journal.

This is an open-access article distributed under the terms and conditions of the Creative Commons Attribution license (http://creativecommons.org/licenses/by/4.0/). 